\title{
Biological Disasters: An Overview of the Covid-19 Pandemic in the First Quarter of 2021
}

\author{
Yakup ARTİK $^{1}$, Nevra Pelin CESUR ${ }^{2}$, Levent KENAR ${ }^{3}$, Mesut ORTATATLI $^{4}$
}

\begin{abstract}
Disaster is defined as the holistic state of natural or human-induced events that develop suddenly, whose controllability requires a systematic approach, which interrupts or stops social life and causes loss of life, property and often cannot be overcome with local capacity. Biological disasters can be human-induced as well as naturally infectious diseases and epidemiological emergencies. Considering the potential of the 21st century, biological disasters have played a role in influenza infections such as Swine Flu (H1N1), Bird Influenza (H5N1), and the Coronavirus family. Considering the disasters in which medical CBRN agents are effective, we evaluated the data in this study to determine the risk management of biological disasters. Since the World Health Organization (WHO) declared a pandemic on March 11, 2020, the first 15 countries are included in the list based on the total cumulative order of the cases and the 12-week case of SARS-CoV-2 in the first quarter of 2021. We tried to evaluate the analysis of data, mortality rates, and the point reached in vaccination within this timeline to provide an overview of 2021 in this research study.
\end{abstract}

Keywords: Biological Disaster, Covid-19, SARS-CoV-2

\section{Biyolojik Afetler: 2021'in İlk Çeyreğinde Covid-19 Pandemisine Genel Bir Bakış}

\begin{abstract}
Özet
Afet, doğal veya insan kaynaklı, aniden gelişen, kontrol edilebilirliği sistematik bir yaklaşım gerektiren, sosyal hayatı kesintiye uğratan veya durduran, can, mal kaybına neden olan ve çoğu zaman yerel kapasite ile üstesinden gelinemeyen bütünsel bir durum olarak tanımlanmaktadır. Biyolojik afetler insan kaynaklı olabileceği gibi, doğal olarak bulaşıcı hastalıklar ve epidemiyolojik olarak da ortaya çıkabilmektedir. 21. yüzyılın potansiyeli düşünüldügünde, Domuz Gribi (H1N1), Kuş Gribi (H5N1) ve Corona virüs ailesi gibi grip enfeksiyonlarında biyolojik afetler rol oynamıştır. Tıbbi KBRN ajanlarının etkili olduğu afetler göz önünde bulundurularak biyolojik afetlerin risk yönetiminin belirlenmesi amacıyla bu çalışmadaki verileri risk yönetimi açısından değerlendirdik. Dünya Sağlık Örgütü'nün (DSÖ) 11 Mart 2020 tarihi ile pandemi ilan etmesinin üzerinden bir yılı aşkın bir süre geçmesi sonucunda vakaların toplam kümülatif sırasına göre listede ilk 15 ülke yer aldı ve 2021 yılının ilk çeyreğinde SARS-CoV-2 haftalık vakası belirlendi. Bu araștırma

\footnotetext{
${ }^{1}$ Genetic and Bioengineering-Master of Science, Chemical, Biological, Radiological, Nuclear Threats and Disaster Risk Management Specialist, TUSEB-Turkey Institutes of Health COVID-19 Diagnostic Center, Ministry of Health University of Health Science, Kanuni Sultan Süleyman Research and Training Hospital, 34303, Kücükcekmece, Istanbul, Turkey

Corresponding author e-posta: ykp.artik@gmail.com ORCID No: 0000-0002-2636-4879

2 Master of Science, Moleculer Biology and Genetic, TUSEB, Turkey Institutes of Health COVID-19 Diagnostic Center, Ministry of Health University of Health Science, Kanuni Sultan Süleyman Research and Training Hospital, 34303, Kücükcekmece, Istanbul, Turkey, e-posta: nevrapelin1970@gmail.com ORCID No: 0000-0003-3979-6053

3 Professor, University of Health Sciences, Departman of Medical Chemical, Biological, Radiological, Nuclear Defense, Etlik, 06010, Ankara, Turkey, e-posta: lkenarmd@gmail.com ORCID No: 0000-0002-6613-1308

${ }^{4}$ Assosciate Professor, University of Health Sciences, Departman of Medical Chemical, Biological, Radiological, Nuclear Defense, Etlik, 06010, Ankara, Turkey, e-posta: mortatatli@gmail.com ORCID No: 0000-0002-7899-6157
} 
çalışmasında 2021 yılına genel bir bakış sağlamak amacıyla verilerin analizini, ölüm oranlarını ve aşılamada gelinen noktayı bu zaman çizelgesi içinde değerlendirmeye çalıştık.

Anahtar Kelimeler: Biyolojik Afet, Covid-19, SARS-CoV-2

\section{INTRODUCTION}

Throughout history, humanity has struggled with many examples of biological threats that resulted in disastrous outbreaks, epidemics, and ultimately pandemics. These biological threats have had a profound impact on society, including economic, political, and demographic consequences, and the deaths of millions of people. For example, epidemic disasters such as cholera, plague, Japanese Encephalitis, and Acute Encephalitis Syndrome can affect a disproportionately large number of societies, populations, or regions at the same time (Morens et al., 2008). As an example, the H1N1 virus, bird flu, or nowadays, SARS-CoV-2 can be described as an example of a pandemic that affects a large region, continent, or even worldwide (Johnson \& Mueller, 2002). A biological disaster is a natural scenario including disease, disability, or death on a large scale among humans, animals, and plants (Özceylan Aubrecht \& Coşkun, 2014). It can be classified as natural, accidental, or intentional (Khabbaz et al., 2014). The disasters caused millions of deaths worldwide, and hundreds of millions of people have suffered varied injuries. The main protection against diseases of biological outbreaks (bioterrorism) is the foremost issue involving the development of mechanisms for the appropriate detection of such outbreaks (Niska \& Burt, 2005). In this study, risk management of biological disasters is evaluated throughout the first quarter of the 2021 COVID-19 overview.

Since the declaration of the pandemic phenomenon on March 11 by WHO, the preparation of vaccines against COVID-19 has been mainly considered for the whole world. It is difficult to predict which type of immune response will result, hence the vaccine will be more effective with the emerging variants of SARS-CoV-2. The first address would be traditional vaccines. However, there are big differences between traditional vaccine development and the development of these vaccines under the pressure of a pandemic. There are many parameters for vaccine production that have implications for early production and up to commercial scale before clinical proof of concept is (Komurcu et al., 2021). There are different approaches that are carried out under financial risks without knowing whether or not the chosen vaccine strategy will be safe and effective. However, these risks are taken mainly by governments (Schirmbeck et al., 1996). Additionally, vaccine strategies are the main subject all over the world. Scientists examine the immune response within the body and the effectiveness of the vaccines to fight the COVID-19 pandemic disaster.

\section{THEORETICAL BASICS}

\subsection{Biological Disaster}

Biological disasters have a considerable and huge impact on society. In particular, they are conveyed by biological vectors. These vectors are microorganisms, toxins, and bioactive substances which can lead to illness, injury, or other health impacts. Additionally, biological agents can be classified based on a) live agents such as viruses, fungi, bacteria, rickettsia, and chlamydia (Manning \& Goldfrank, 2002). Toxins are chemical agents derived from bacteria, fungi, plants, and animals of biological origin (poison). For example, biological disasters, plant and animal contagion, insects or other animal plagues and infestations, or even epidemic diseases can be shown (Bland, 2014).

Disaster is the result of natural or man-made hazards. Many pandemics have struck humanity, including the plague, measles, yellow fever, Ebola, and SARS (Varol \& Buluş Kırıkkaya, 2017). One 
of the earliest records of an emerging infectious disease is the devastating Plague of Athens, which killed 40,000 people. The Black Death (1347-1350) claimed the lives of 50 million people (Morens et al., 2008). After that, until the 1900s, the plague became a fearful biological disaster in many countries. The 1918 Spanish flu (H1N1), the 1957 Asian flu (H2N2), and the 1968 Hong Kong flu (H3N2) caused 50 million, 1.5 million, 1 million, and 300,000 human deaths, respectively (Johnson \& Mueller, 2002) (Simonsen et al., 1998). In recent years, the other biological disasters have been the West Africa Ebola virus disease (EVD) outbreak of 2013-2016, which affected mainly three West African countries: Guinea, Liberia, and Sierra Leone. With significant local transmission, the Ebola virus demonstrated a high ability to spread through other African countries, as well as Europe and the United States (Spengler et al., 2016). However, nowadays, a new type of SARSCoV-2 is affected the all over the world with deadly pandemic (Ansart et al., 2009).

Since the early 21st century, three types of coronavirus family have been affected by people with deadly pneumonia around the world, including SARS-CoV, MERS-CoV, and nowadays, SARS-CoV2. In 2003, a severe acute respiratory syndrome coronavirus (SARS-CoV) emerged in Guangdong providence in China, affecting 8098 people in 29 different countries. However, in 2012, the Middle-East respiratory syndrome coronavirus (MERS-CoV) emerged in Saudi Arabia and affected 27 different countries. MERS-CoV had a higher mortality rate (35\%) than SARS-CoV (9\%) (Lam et al., 2003). In December 2019, a new type of coronavirus family member, SARS-CoV-2, caused a global pandemic episode in the entire world in the Chinese city of Wuhan. While the actual virus source has not been confirmed yet, various sequence-based studies have demonstrated considerable similarity with the bat's sequence (Shereen et al., 2020).

SARS-CoV-2 causes a deadly disease termed COVID-19 disease. People infected with viruses through contaminated surfaces, respiratory droplets, close contact, and people contacted with these parameters were infected by the virus. The COVID-19 contagious period is not known exactly. However, the incubation time of disease varies between 2-14 days generally. The mean incubation time is described as almost 5.84 (99\% Confidence Interval 4.8-6.8) days and the median incubation time is 4.8 days (Di Mascio et al., 2020). Meanwhile, R0 basic reproduction is the number of different individuals that an infected individual will infect during the period of infectious disease in a population that is all susceptible (Kwok et al., 2020). The value of $\mathrm{R}_{0}$ is 2 and 5 for SARS and $0.3-0.8$ for MERS. If the $\mathrm{R}_{0}$ rate is greater than 1 , multiple new infections can emerge from each existing infection (Bauch, 2021). This episode finally ends with the epidemic. In the modeling reported for COVID-19, the $\mathrm{R}_{0}$ value of COVID-19 was found to be between 1.4 and 6.49. This is the main proof that the contagion effect of SARS-CoV-2 is significantly more rapid than SARS-CoV or MERS-CoV (Turan \& Hacımustafaoğlu, 2020).

The detection of SARS-CoV-2 in clinical practice is important to limit the spread of the infection. The reliable diagnosis of the infected people is provided by nasal swab tests with q-PCR, serological tests, and CT results. The RT-PCR nasal swab sensitivity is 63\% (Vellingiri et al., 2020), pharyngeal 32\%, swab chest CT 97\% (Ai et al., 2020) and blood test ELISA 93-99\%, respectively (Guo et al., 2020). On the other hand, before the infection, the governments of various countries offered various preventions such as self-quarantine, mask rules, and closing public places so as to provide public safety and limit social interactions. Furthermore, according to the WHO, protective measures include a) disinfecting your hands with an alcohol-based hand sanitizer; b) avoiding contacting your eyes, nose, and mouth while outside; c) being aware of the virus; d) avoiding crowded public places; and e) encouraging women who have babies to breastfeed to increase their immunity (Vellingiri et al., 2020).

\subsection{Bioterrorism}

Bioterrorism is the deliberate release of bacteria, viruses, or other micro-organisms that can sicken or kill people, animals, and crops (URL 1). Many infectious agents have been responsible 
for biological disasters. Although COVID-19 has not yet been qualified as a bioterrorism agent, it may be possible to be included in medical CBRN agents. The biological agents are evaluated into the three categories (A, B, and C) by the Centers for Disease Control and Prevention (CDC) and the National Institute of Allergy and Infectious Diseases. Part A consists of pathogens that pose the highest risk to national safety and public health. The categories are based on the ability to spread or communicate from person to person, causing a major impact on public health, causing high mortality, causing public panic and social disruption, and requiring special preparedness needs. On the other hand, Category-B agents are the second-highest risk group that is relatively easy to spread. The rates of disease are moderate, and death rates are lower. The agents in Category $\mathrm{C}$ are listed as agents that can be used in biological attacks in the future when evaluated according to their easy availability, easy production, spreading, and their potential to cause a high rate of disease and death and have a great impact on health. Health systems need diagnostic methods and monitoring systems for diseases caused by this category of agents (Workgroup, 2000)(Kwon et al., 2018). In Table1, high-priority biological agents and toxins are summarized based on CDC data.

Table 1. CDC High-Priority Biological Agents and Toxins (URL 2)

\begin{tabular}{|c|c|c|}
\hline Category A & Category B & Category C \\
\hline $\begin{array}{l}\text { Anthrax } \\
\text { (Bacillus anthracis) }\end{array}$ & $\begin{array}{l}\text { Brucellosis } \\
\text { (Brucella species) }\end{array}$ & Nipah virus \\
\hline $\begin{array}{l}\text { Botulism } \\
\text { (Clostridium botulinum toxin) }\end{array}$ & $\begin{array}{l}\text { Epsilon toxin of } \\
\text { Clostridium perfringens }\end{array}$ & Hanta virus \\
\hline $\begin{array}{l}\text { Plague } \\
\text { (Yersinia pestis) }\end{array}$ & $\begin{array}{l}\text { Food safety threats } \\
\text { (Salmonella species, } \\
\text { Escherichia coli 0157:H7, Shigella) }\end{array}$ & \\
\hline $\begin{array}{l}\text { Smallpox } \\
\text { (variola major) }\end{array}$ & $\begin{array}{l}\text { Glanders } \\
\text { (Burkholderia mallei) }\end{array}$ & \\
\hline $\begin{array}{l}\text { Tularemia } \\
\text { (Francisella tularensis) }\end{array}$ & $\begin{array}{l}\text { Melioidosis } \\
\text { (Burkholderia pseudomallei) }\end{array}$ & \\
\hline $\begin{array}{l}\text { Viral hemorrhagic fevers, } \\
\text { including }\end{array}$ & $\begin{array}{l}\text { Psittacosis } \\
\text { (Chlamydia psittaci) }\end{array}$ & \\
\hline $\begin{array}{l}\text { Filoviruses } \\
\text { (Ebola, Marburg) }\end{array}$ & $\begin{array}{l}\text { Q fever } \\
\text { (Coxiella burnetii) }\end{array}$ & \\
\hline \multirow[t]{5}{*}{$\begin{array}{l}\text { Arenaviruses } \\
\text { (Lassa, Machupo) }\end{array}$} & $\begin{array}{l}\text { Ricin toxin from Ricinus communis } \\
\text { (castor beans) }\end{array}$ & \\
\hline & Staphylococcal enterotoxin B & \\
\hline & $\begin{array}{l}\text { Typhus fever } \\
\text { (Rickettsia prowazekii) }\end{array}$ & \\
\hline & Viral encephalitis & \\
\hline & $\begin{array}{l}\text { Vibrio cholerae, } \\
\text { Cryptosporidium parvum }\end{array}$ & \\
\hline
\end{tabular}

SARS-CoV-2 has not yet been identified as an agent of bioterrorism, but it has entered our literature as a global biological disaster (Hsieh et al., 2021). It was revealed that the focus was on four different results, with the team set up to research how the virus emerged in China. These are 
a) the transition from a bat to human, b) transmission from wild animals market to human via a live or non-living intermediate host from bat, c) transmission from the vaccine institute in China, d) bioterrorism and the work on these scenarios (URL 3).

\section{THE FIRST QUARTER OF COVID-19 OVERVIEW}

The SARS-CoV-2 causes an unusual viral pneumonia epidemic. In 2019, various healthcare facilities in Wuhan reported pneumonia patient clusters of an unknown cause (Yilmaz Gulec et al., n.d.). Similar to the other members of the Coronavirus family, COVID-19 patients show some symptoms such as cough, chest discomfort, fever, dyspnea, or bilateral lung infiltration, etc. Among the first 27 hospitalized patients, most of the cases were epidemiologically linked to the Huanan Seafood Wholesale Market, which sells not only seafood but also live animals, including poultry and wildlife. According to a retrospective study, the onset of the first known case dates back to December 8, 2019 (Zunyou Wu \& McGoogan, 2020). On 31 December, the Wuhan Municipal Health Commission informed unidentified pneumonia and notified WHO (Zunyou Wu \& McGoogan, 2020). The Chinese scientists started analyzing metagenomic RNA sequencing of viruses isolated from bronchoalveolar lavage fluid samples of patients. As a result of the analysis, never-before-seen beta-coronaviruses are described. The first genome sequence of the novel coronavirus was described on the Virological website on January 10. Additionally, the complete genome sequences identified on January 12 in the GISAID database show subsequently, more patients were identified with no history of exposure to Huanan Seafood Wholesale Market. A few familial clusters and nosocomial infections have been reported, which are clear evidence of human-to-human transmission of the new virus. Meanwhile, inter-city travel prior to the festival made it easier to contract the virus in China. The spread of this novel type of coronavirus is so fast in other cities in Hubei province and other parts of China. At the end of January 15, the number of approved cases skyrocketed, and thousands of new cases were diagnosed each day. On January 30, the novel coronavirus outbreak was declared and on February 11, the International Committee on Virus Taxonomy named the new coronavirus as "SARS-CoV-2" and WHO named the disease "COVID-19" (Hu et al., 2021).

The total number of cases showed a huge increase in early February based on the declaration of China's National Health Commission (an average rate of more than 3,000 new confirmed cases per day). To control COVID-19, China started stringent public health measures such as closing Wuhan city on January 23, blocking all transportation and travel connecting the city. A few weeks later, all outdoor events and gatherings were restricted. Thanks to these precautions, the number of new cases per day in China has shown a steadily decreasing trend (Zhiwei Wu et al., 2021).

Although there was a downward ratio in China, the international spread increased at the end of February. Especially, international travel enabled the rapid spread of COVID-19 worldwide. Ultimately, WHO officially declared the global COVID-19 outbreak a pandemic on March 11, 2020. The Johns Hopkins University Center for Systems Science and Engineering's COVID-19 dashboard reported that the 216 countries and territories from six continents have more than 733,000 cases of COVID-19. The USA was one of the countries with the most cases so far (Zhou et al., 2020) (Dong et al., 2020).

\section{SARS-COV-2 INFECTION, PREVENTION AND TREATMENT}

Although sequence-based studies describe that SARS-CoV-2 is probably a natural virus originating from animals, there is no proof of when or where the virus first entered humans. Before the pandemic episodes all over the world, a study from France detected SARS-CoV-2 by PCR in a 
stored sample from a patient. However, this retrospective study does not provide evidence of the origin and contamination of SARS-CoV-2 (Guo et al., 2020).

The COVID-19 disease is termed a highly pathogenic virus. COVID-19 has affected more than 88 million people in various countries all over the world as of January 10, 2021. The RNA virus structural form of the SARS-CoV-2 is a $30 \mathrm{~kb}$ genome with 14 open reading frames encoded by the spike protein $(\mathrm{S})$, nucleocapsid protein $(\mathrm{N})$, a small membrane protein $(\mathrm{SM})$, and membrane glycoprotein (M) with an additional membrane glycoprotein (HE) as shown in (Figure 1) (Shu \& McCauley, 2017) (Jasper J. et al., 2017) . The SARS-CoV-2 is an RNA virus enveloped by positively single-stranded large RNA beta which can infect not only humans but also a wide range of animals. The angiotensin-converting enzyme 2 (ACE2) receptor on the host can be associated with this enveloped virus to infect respiratory cells (Macnaughton \& Davies, 1987). This receptor is located in all alveolar type II cells of the lung and also in the aerodigestive tract, including the mucosa of the oral cavity (Shang et al., 2020).

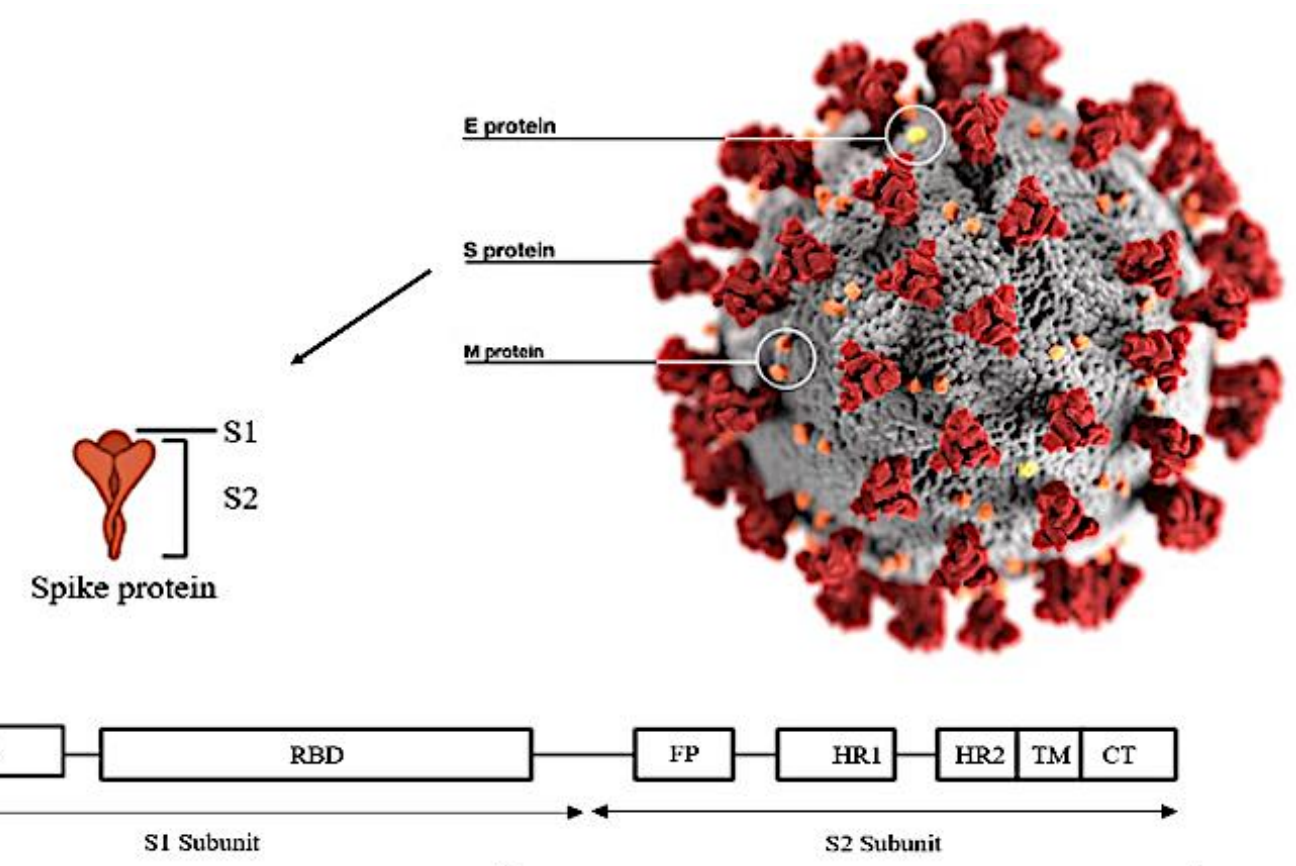

Figure 1. The structural form of SARS-CoV-2

The SARS-CoV-2 virus has mutated in order to stay alive in a host. The accumulation of the virus mutations is because of polymerase fidelity, the cellular environment, host immune responses, gene editing, or natural selection. Although SARS-CoV-2 has higher accuracy in its transcription and replication process than other RNA viruses, 13,402 single mutations have been described (Wang et al., 2020). According to this information, a new type of coronavirus has been described in the UK that has already infected $1 / 4$ of the total cases. It reached $2 / 3$ of those infected in the UK. The British variant spreading rate is higher than $70 \%$ of cases compared to the normal SARSCoV-2 with an R index growth of 0.4. This new type is mutated at the N501Y spike protein level, involving 23 separate mutations on the spike, 17 of which are linked to the virus proteins (Daniloski et al., 2021). Although SARS-CoV-2 has been mutated, mutations are not decisive for its biological behavior and also do not cause crucial changes in the structure of the virus. Although the virus's structure is unlikely to be affected, the virus's effectiveness is reduced. Thus, patients think that vaccine strategies will also be effective against variant forms of the virus. Today, the globally dominant D614G mutation emerged in Europe in February 2020. Studies show that new variants are rapidly spreading across the continents. This variant additionally demonstrated high viral growth and was less detectable with the RT-PCR technique in the laboratory. When the 
D614G mutations were compared with the British variant, D614G had more severe effects on the respiratory tract and lungs (Volz et al., 2020). Also, in the location of the spike protein, another variant is described as the E484K mutation. It is a combination of different variants and has already been found in the South African (B.1.351) and Brazilian (B.1.1.28) variants. On 1 February, Public Health England (PHE) reported that the COVID-19 Genomics (COG-UK) consortium had described this same E484K mutation in 11 samples having the UK variant B.1.1.7 with 214159 sequence analyses (Public Health England, 2020).

The SARS-CoV-2 is a novel virus type for human beings and the nature of the immune responses is not completely unraveled which vaccine process will be most effective. It has been examined in similar ways to SARS-CoV or MERS-CoV emerging evidence of symptoms. All three exhibit suppressive innate immune system activation beginning on dendritic cells, as well as responses that dampen antiviral type I and type III interferons (Remy et al., 2020) (Blanco-Melo et al., 2020). The detection of the virus is characterized by an increase in the number of neutrophils and monocytes in the bloodstream. The rate of CD14+ and CD16+ monocyte-derived macrophages is significant for the detection of which cells are located in the airway. Furthermore, inflammatory cytokines and chemokines are also examined. If the virus is not diagnosed early, the respiratory tract is influenced by a high viral burden and acute respiratory distress syndrome (Liao et al., 2020). Thus, in the COVID-19 vaccine design, a novel thought of trial immunity (Box1) concept is raised, especially in the early infection phase.

The first candidate SARS-CoV-2 vaccine was utilized on March 16, 2020, in human clinical tests. For vaccine strategy and development, the $S$ protein is the main element that plays a key role in virus neutralizing-antibodies to correlate the immune system for vaccine protection. Since COVID19 is a new type of coronavirus, vaccination strategies can be compared with other family members of the coronavirus. These $\mathrm{S}$ protein-based vaccine strategies for the SARS-CoV, MERS$\mathrm{CoV}$ and other coronavirus types include many safety concerns involving immunopathological and inflammatory side-effects such as antibody-dependent disease enhancement (ADE) or infiltration of pulmonary eosinophilic cells into the lung (Agrawal et al., 2016). Because of the ADE, entering macrophages expressed by $\mathrm{FCR}$ are considered to cause the generation of proinflammatory cytokines (IL-6, IL-8, and MCP1) and loss of tissue-repaired cytokine (TGF) by stimulation of macrophages (Liu et al., 2019). Therefore, during the application and development of the COVID19 vaccine to humans in clinical trials, we should be careful to prevent any undesired responses because of the ADE antibodies against coronaviruses (Hashem et al., 2019).

Mutations occur during the transmission of viruses from person to person. Cases of mutations have been increasing lately. Stopping an epidemic is one method of stopping the spread of a disease in the community. In addition, implementing this policy is not a correct approach for humanity with legal dimensions. Coronavirus and influenza are infectious diseases, not microorganism diseases like smallpox and measles. A person with COVID-19 disease can be caught again. For this reason, the illness of society and the policy of immunization are still being debated in the scientific world. The average ratio of the world population's total cases has been shown as 6.54 (Table 2). The USA, Spain and France are above this average value.

Herd immunity is the foremost issue in overcoming the COVID-19 disease. The threshold of herd immunity is described as the percentage of individuals in a population who have acquired immunity. Its threshold is utilized based on the basic reproduction number $\left(\mathrm{R}_{0}\right)$ and is calculated as $11 / R_{0}$. The $R_{0}$ value of a highly communicable pathogen such as measles is typically ranged between 12-18. That means a high proportion of the population must be immune to decrease sustained transmission. On the other hand, the deadly phenomena of SARS-CoV-2 demonstrate an $\mathrm{R}_{0}$ value range of 2 to 3.2. According to data, population immunity does not create immunity because all individuals are equally susceptible and equally infectious (Omer et al., 2020). 
Table 2. The Ratio of the World Population to COVID-19 Cases in the First 12 Weeks of 2021 (URL 4)

\begin{tabular}{|c|c|c|c|c|}
\hline NO & COUNTRIES & POPULATION & $\begin{array}{r}\text { TOTAL WHO } \\
\text { CONFIRMED } \\
\text { CASES }\end{array}$ & $\begin{array}{r}\text { POPULATION/ } \\
\text { CONFIRMED } \\
\text { CASES \% }\end{array}$ \\
\hline 1 & United States of America & 330.160 .000 & 29.921 .599 & 9,06 \\
\hline 2 & Spain & 47.100 .000 & 3.247 .738 & 6,90 \\
\hline 3 & France & 67.422 .000 & 4.472 .071 & 6,63 \\
\hline 4 & The United Kingdom & 66.797 .000 & 4.333 .046 & 6,49 \\
\hline 5 & Italy & 59.640 .000 & 3.532 .057 & 5,92 \\
\hline 6 & Poland & 38.352 .000 & 2.267 .964 & 5,91 \\
\hline 7 & Brazil & 212.675 .000 & 12.490 .362 & 5,87 \\
\hline 8 & Argentina & 45.377 .000 & 2.301 .389 & 5,07 \\
\hline 9 & Colombia & 50.374 .000 & 2.375 .591 & 4,72 \\
\hline 10 & Turkey & 83.155 .000 & 3.208 .173 & 3,86 \\
\hline 11 & Germany & 83.218 .000 & 2.782 .273 & 3,34 \\
\hline 12 & Russian Federation & 146.749 .000 & 4.528 .543 & 3,09 \\
\hline 13 & Iran & 83.993 .000 & 1.855 .674 & 2,21 \\
\hline 14 & Mexico & 128.933 .000 & 2.224 .767 & 1,73 \\
\hline \multirow[t]{3}{*}{15} & India & 1.370 .000 .000 & 12.039 .644 & 0,88 \\
\hline & TOTAL LIST & 1.084 .270 .000 & 70.932 .263 & 6,54 \\
\hline & GLOBAL & 7.790 .000 .000 & 126.890 .643 & 1,63 \\
\hline
\end{tabular}

During the pandemic episode of COVID-19, both naturally acquired and vaccine-induced immunity were a critical point in determining population-level protection and sustaining herd immunity. The actual conservation of this devastating biological disaster has tried to be provided with vaccine strategies recently by the scientific world. Currently, various vaccine strategies have been studied, including live attenuated viruses, inactive virus-like particles, synthetic peptides, DNA/RNA, recombinant bacterial vectors, and recombinant viral vector-based vaccine strategies. The first candidate for the SARS-CoV-2 vaccine has been described on March 16, 2020, with human clinical tests. According to data, three-phase I vaccine candidates, 11 preclinical vaccines, and 26 research-stage vaccines are currently in use around the world (Pehlivan et al., 2019).

We can solve social immunity with a vaccination strategy. The rates of social immunity gained by vaccination compared to the population of the countries were compared with the total vaccination rate (5.94\%) of the world population (Table 3). India, Mexico, Colombia and Iran are vaccinated compared to the population of the 15 countries with the highest number of cases and are below the world average. When evaluating social immunization by vaccination compared to the population of the country, the best managers are the first three countries: the United Kingdom, the USA, and Turkey, respectively. However, when we make a ranking for countries that plan to 
achieve social immunity by vaccination and increasing the spread of cases compared to the population, the world average is seen as 7.57. Compared with the average value of the world population, the increase in social immunity by vaccination (Table $2,5.94 \%$ ) and the average of the world population's spread of social immunity and the rate of immunization by vaccination (Table $3,5.94 \%$ ) However, considering the average of the world population of the vaccine (Table 3, $5.94 \%$ ), the USA is 9.06 , Spain as 6.90 , France as 6.63 , and the UK as 6.49 , respectively. The ratio of the average number of cases above their values (Table $3,5.94 \%$ ) to the population is higher. It is at the limit value (approximately 5\%) in Italy, Poland, Malaysia, and Argentina. In other words, in countries that approach this strategy or cannot control the increasing cases, vaccination should be increased much more. The process should be accelerated in order to reduce the rate of cases compared to the population at a lower level than the world average rate. Thus, the ratio of the population of the countries to the cases seen is below the world average of vaccination and increasing the vaccination more than the average cases seen can provide the rapid resolution of the pandemic. In other words, vaccination in these countries should be done faster than in other countries. In addition, there are only two countries in the list where the vaccination rate by population is less than the number of cases seen compared to the population. Colombia and Iran must urgently increase vaccination rates and social immunity above the level seen in the country.

Table 3. The Ratio of the World Population to COVID-19 Vaccine and COVID-19 Cases and People Who Have COVID-19 Vaccine in the First 12 Weeks of 2021 (URL 4)

\begin{tabular}{llrrrr} 
NO & COUNTRIES & $\begin{array}{r}\text { VACCINE } \\
\text { DATE }\end{array}$ & $\begin{array}{r}\text { VACCINE } \\
\text { POPULATION }\end{array}$ & $\begin{array}{r}\text { POPULATION/ } \\
\text { VACCINE } \\
\text { POPULATION \% }\end{array}$ & $\begin{array}{r}\text { POPULATION/ } \\
\text { CONFIRMED+ } \\
\text { VACCINE(\%) }\end{array}$ \\
\hline $\mathbf{1}$ & The United Kingdom & 18.03 .2021 & 31.186 .362 & 46,69 & 53,18 \\
\hline $\mathbf{2}$ & United States of America & 15.03 .2021 & 118.170 .648 & 35,79 & 44,85 \\
\hline $\mathbf{3}$ & Turkey & 15.03 .2021 & 13.969 .867 & 16,80 & 20,66 \\
\hline $\mathbf{4}$ & Spain & 22.03 .2021 & 6.332 .491 & 13,44 & 20,34 \\
\hline $\mathbf{5}$ & Poland & 15.03 .2021 & 5.117 .328 & 13,34 & 19,26 \\
\hline $\mathbf{6}$ & Germany & 22.03 .2021 & 10.886 .389 & 13,08 & 16,43 \\
\hline $\mathbf{7}$ & Italy & 18.03 .2021 & 7.734 .372 & 12,97 & 18,89 \\
\hline $\mathbf{8}$ & France & 18.03 .2021 & 8.629 .076 & 12,80 & 19,43 \\
\hline $\mathbf{9}$ & Russian Federation & 18.03 .2021 & 10.600 .000 & 7,22 & 10,31 \\
\hline $\mathbf{1 0}$ & Argentina & 23.03 .2021 & 2.939 .364 & 6,48 & 11,55 \\
\hline $\mathbf{1 1}$ & Brazil & 15.03 .2021 & 13.028 .391 & 6,13 & 12,00 \\
\hline $\mathbf{1 2}$ & India & 21.03 .2021 & 54.665 .820 & 3,99 & 4,87 \\
\hline $\mathbf{1 3}$ & Mexico & 14.03 .2021 & 4.947 .552 & 3,84 & 5,56 \\
\hline $\mathbf{1 4}$ & Colombia & 18.03 .2021 & 1.077 .476 & 2,14 & 6,85 \\
\hline $\mathbf{1 5}$ & Iran & 24.03 .2021 & 77.475 & 0,09 & 2,30 \\
\hline & TOTAL LísT & $\mathbf{2 4 . 0 3 . 2 0 2 1}$ & $\mathbf{2 0 2 . 0 2 6 . 5 3 3}$ & $\mathbf{2 6 , 0 4}$ & $\mathbf{3 2 , 9 7}$ \\
\hline & GLOBAL & $\mathbf{2 4 . 0 3 . 2 0 2 1}$ & $\mathbf{4 6 2 . 8 2 4 . 3 7 4}$ & $\mathbf{5 , 9 4}$ & $\mathbf{7 , 5 7}$ \\
\hline & & & & \\
\hline
\end{tabular}


From the first time that the COVID-19 outbreak occurred, the 15 countries that were notified by WHO with the date 30.03.2021 and with the highest number of cases are included in the (Table 4). The total cases seen in these countries constitute $72.17 \%$ of the total cases seen in the world. These 15 countries are at the level of $74.07 \%$ in the ratio of all deaths to all deaths in the world. This rate is too serious to be ignored. If the 15 countries with the highest number of cases in the world are taken into consideration during the vaccination process, it highlights the judgments that the pandemic risk process will be taken under control.

Table 4. Who Total COVID-19 30.03.2021 (URL 4)

\begin{tabular}{llrrrr}
\hline NO & COUNTRIES & $\begin{array}{r}\text { CONFIRMED } \\
\text { CASES }\end{array}$ & \% & DEATHS & \% \\
\hline $\mathbf{1}$ & United States of America & 29.921 .599 & 23,58 & 543.870 & 19,57 \\
\hline $\mathbf{2}$ & Brazil & 12.490 .362 & 9,84 & 310.550 & 11,18 \\
\hline $\mathbf{3}$ & India & 12.039 .644 & 9,49 & 161.843 & 5,82 \\
\hline $\mathbf{4}$ & Russian Federation & 4.528 .543 & 3,57 & 98.033 & 3,53 \\
\hline $\mathbf{5}$ & France & 4.472 .071 & 3,52 & 94.042 & 3,38 \\
\hline $\mathbf{6}$ & The United Kingdom & 4.333 .046 & 3,41 & 126.592 & 4,56 \\
\hline $\mathbf{7}$ & Italy & 3.532 .057 & 2,78 & 107.933 & 3,88 \\
\hline $\mathbf{8}$ & Spain & 3.247 .738 & 2,56 & 74.420 & 2,68 \\
\hline $\mathbf{9}$ & Turkey & 3.208 .173 & 2,53 & 31.076 & 1,12 \\
\hline $\mathbf{1 0}$ & Germany & 2.782 .273 & 2,19 & 75.913 & 2,73 \\
\hline $\mathbf{1 1}$ & Colombia & 2.375 .591 & 1,87 & 62.790 & 2,26 \\
\hline $\mathbf{1 2}$ & Argentina & 2.301 .389 & 1,81 & 55.368 & 1,99 \\
\hline $\mathbf{1 3}$ & Poland & 2.267 .964 & 1,79 & 51.932 & 1,87 \\
\hline $\mathbf{1 4}$ & Mexico & 2.224 .767 & 1,75 & 201.429 & 7,25 \\
\hline $\mathbf{1 5}$ & Iran & 1.855 .674 & 1,46 & 62.397 & 2,25 \\
\hline & TOTAL LísT & $\mathbf{9 1 . 5 8 0 . 8 9 1}$ & $\mathbf{7 2 , 1 7}$ & $\mathbf{2 . 0 5 8 . 1 8 8}$ & $\mathbf{7 4 , 0 7}$ \\
\hline & GLOBAL & $\mathbf{1 2 6 . 8 9 0 . 6 4 3}$ & $\mathbf{1 0 0 , 0 0}$ & $\mathbf{2 . 7 7 8 . 6 1 9}$ & $\mathbf{1 0 0 , 0 0}$ \\
\hline & & & & \\
\hline & & & & \\
\hline
\end{tabular}

When the focus is on pandemic risk management in 2020, all countries have gained experience with their methods. Despite this situation, when the data obtained in the first quarter of 2021 are evaluated with the numbers reported by WHO as of 30.03.2021, comparing the cases given in (Table 5) with the cases and mortality rates given in (Table 6) is more difficult in the second year compared to the first year of the pandemic. We can guess that it will pass.

Considering the risk management of the pandemic; evaluation can be categorized under two main headings as preventive measures and mitigating measures. These two titles; phase and risk mitigation strategies, type of risk mitigation strategies, nature and implementation of risk mitigation strategy, and warnings are discussed. Preventive measures can be achieved by avoiding direct contact/interaction/handling with animals, which is extremely difficult to implement on the pre-pandemic, innate risk reduction strategy. Many known mammals play a 
vital role in human life but act as potential sources and/or carriers of viruses. For example, MARBURG 1967 (bat), EBOLA 1976 (bat), SARS 2002 (bat), SARS 2012- (bat), SARS-CoV-2 2019 (assuming bat) MERS 2010 - (Camels), H5N1 (Bird chimney), 2003- (Chicken), H7N9 (Bird Chimney), 2013- (Chicken) can be given (Johnson \& Mueller, 2002) (Simonsen et al., 1998). When we focus on risk reduction strategies during the pandemic, the active use of home delivery services and a work-from-home strategy, avoiding physical interaction with others play an important role. In addition, it is necessary to enforce quarantine, school and work closures, limit large gatherings, frequent hand washing, disinfection, avoid touching the face. Social distancing, avoiding crowds, imposing restrictions on the use of public transport are among the pandemic risk management strategies. Again, during the pandemic, prudence to the vaccine appears to be the most effective strategy, along with the administrative recommendations that should be followed by individuals. It provides the fastest way to minimize the impact of the pandemic, provided the vaccine is available and accessible to all. The nature and implementation of the risk reduction strategy from preventive risks during the pandemic can only be revealed with engineering applications (Alauddin et al., 2021). It can be achieved through the use of herd protection, genetics or diet to strengthen the immune system and raise management awareness of person tracing, rapid test status and safe handling procedures, in line with administrative advice that should be implemented at the individual and community level. This is an effective passive strategy, but highly variable depending on the individual's immune system. In terms of risk reduction, when we consider preventive measures during the pandemic, again redesigning/installing security layers in interactive systems is an effective strategy to minimize the spreading of the disease but requires proper planning and implementation. Self-isolation, wearing masks, personal protective equipment, good hygiene practices, and surface cleaning is a procedural type of risk reduction strategy. The strategy's effectiveness depends on individuals following best practices. These procedures may require peer pressure and police intervention for the procedural activities of administrative management, but special attention and guidelines for vulnerable groups should be incorporated into the risk management strategy. Significant resources are required to implement these measures. The nature and implementation of the risk reduction strategy is made possible by the administrative advice that should be implemented by individuals and organizations. Administrative advice that should be implemented at the individual and community level are effective mechanisms to prevent an outbreak. But not all individuals and transactions can be online. There is also the possibility of default, depending on the level of administrative action (recommendation, necessity and implementation). It is difficult to activate, enforce and control effective mechanisms in minimizing the effects of the pandemic. They cause significant economic losses. When looking at mitigation measures, stage and risk reduction activities are possible by applying by management and administrative services as a type of procedural risk reduction strategies to quarantine and treat cases exposed during the pandemic, improve health systems, expand hospitals, workers, antidotes (Alauddin et al., 2021). Although the pandemic is not over yet, all these risk management strategies have emerged as of March 11, 2020 and have been procedurally published by the countries' own policies (Komurcu et al., 2021). All these experiences and experiences reveal that decisions must be made in order to activate strategies effectively and mobilize resources. Evaluating these risk managements requires longterm planning, the widespread epidemic can be used to upgrade health systems to respond well to future outbreaks.

During a pandemic, four phases are observed. These are the initial, increase, peak, and decrease periods. After the decrease period, there may be a second wave, or even a third wave may be observed until the seasonal pattern returns. Seasonal influenza can occur after a pandemic. Because seasonal flu is strengthened by new genetic material. For this reason, no matter how much experience countries gain, mutations of the virus caused by genetic effects indicate that countries will go through more difficult processes. The inability to constantly revise the vaccine creates a disadvantage for herd immunity. These four phases are generally seen in epidemics, 
however, pandemics do not always follow a pattern and each may be different from each other (Sezen, 2009).

Whenever herd immunity occurs, it decreases below the peak point. Considering the rapidly mutating variants of the virus, such as COVID-19, which become more resistant to humans, it can be predicted that the increase in mutations will create new peak waves of the pandemic. The stages of the epidemic in epidemiology can be better observed retrospectively after the end of the pandemic. Since we are in the pandemic, we can only follow the epidemic stages seasonally. Before the pandemic ends, it is not possible to predict whether it is in the peak phase or in a decreasing trend. In the epidemic phase, which is called the 1st and 2nd wave, when the increase is seen before the epidemic ends, there is another new wave emerges. However, it is not possible to talk about a wave again before the epidemic is completely over. Tracking the epidemic is calculated with the R0 value. Epidemiologist mac Donald used it to describe the transmissibility of malaria. As per his suggestion, if $\mathrm{R} 0<1$, the disease will perish in the population, and if $\mathrm{R} 0>1$, the disease will spread faster (Achaiah et al., 2020). These calculations are as follows for countries that have successfully managed risk management. Moreover, interventions to reduce the transmission of SARS-CoV-2 cause the epidemic curve to flatten. These provide delaying the peak of the epidemic and saving time. Thus, it reduces the burden and threats on health services and causes a decrease in the total number of cases (Sezen, 2009).

Table 5. 2021 First 3 Months (12 Week) (URL 4)

\begin{tabular}{llrrrr}
\hline NO & COUNTRIES & $\begin{array}{r}\text { CONFIRMED } \\
\text { CASES }\end{array}$ & \% & DEATHS & \% \\
\hline $\mathbf{1}$ & United States of America & 9.884 .483 & 23,49 & 197.750 & 20,74 \\
\hline $\mathbf{2}$ & Brazil & 4.703 .836 & 11,18 & 111.701 & 11,72 \\
\hline $\mathbf{3}$ & France & 1.835 .930 & 4,36 & 29.341 & 3,08 \\
\hline $\mathbf{4}$ & The United Kingdom & 1.729 .391 & 4,11 & 52.003 & 5,45 \\
\hline $\mathbf{5}$ & India & 1.647 .659 & 3,91 & 12.117 & 1,27 \\
\hline $\mathbf{6}$ & Italy & 1.371 .252 & 3,26 & 32.651 & 3,42 \\
\hline $\mathbf{7}$ & Russian Federation & 1.283 .045 & 3,05 & 39.234 & 4,12 \\
\hline $\mathbf{8}$ & Spain & 1.253 .726 & 2,98 & 20.455 & 2,15 \\
\hline $\mathbf{9}$ & Germany & 1.006 .735 & 2,39 & 41.598 & 4,36 \\
\hline $\mathbf{1 0}$ & Turkey & 947.080 & 2,25 & 9.628 & 1,01 \\
\hline $\mathbf{1 1}$ & Poland & 932.429 & 2,22 & 22.765 & 2,39 \\
\hline $\mathbf{1 2}$ & Mexico & 782.660 & 1,86 & 74.355 & 7,80 \\
\hline $\mathbf{1 3}$ & Colombia & 712.457 & 1,69 & 19.150 & 2,01 \\
\hline $\mathbf{1 4}$ & Argentina & 661.457 & 1,57 & 11.916 & 1,25 \\
\hline $\mathbf{1 5}$ & Iran & 609.449 & 1,45 & 6.870 & 0,72 \\
\hline & TOTAL LiST & $\mathbf{2 9 . 3 6 1 . 5 8 9}$ & $\mathbf{6 9 , 7 6}$ & $\mathbf{6 8 1 . 5 3 4}$ & $\mathbf{7 1 , 4 8}$ \\
\hline & GLOBAL & $\mathbf{4 2 . 0 8 7 . 8 4 0}$ & $\mathbf{1 0 0 , 0 0}$ & $\mathbf{9 5 3 . 4 0 1}$ & $\mathbf{1 0 0 , 0 0}$ \\
\hline & & & & \\
\hline
\end{tabular}


Table 6. The Difference Between 2020-2021 2021 First 3 Months (12 Week) (URL 4)

\begin{tabular}{llrrrr}
\hline NO & COUNTRIES & $\begin{array}{r}\text { CONFIRMED } \\
\text { CASES }\end{array}$ & \% & DEATHS & \% \\
\hline $\mathbf{1}$ & United States of America & 20.037 .116 & 23,63 & 346.120 & 18,96 \\
\hline $\mathbf{2}$ & India & 10.391 .985 & 12,25 & 149.726 & 8,20 \\
\hline $\mathbf{3}$ & Brazil & 7.786 .526 & 9,18 & 198.849 & 10,89 \\
\hline $\mathbf{4}$ & Russian Federation & 3.245 .498 & 3,83 & 58.799 & 3,22 \\
\hline $\mathbf{5}$ & France & 2.636 .141 & 3,11 & 64.701 & 3,54 \\
\hline $\mathbf{6}$ & The United Kingdom & 2.603 .655 & 3,07 & 74.589 & 4,09 \\
\hline $\mathbf{7}$ & Turkey & 2.261 .093 & 2,67 & 21.448 & 1,18 \\
\hline $\mathbf{8}$ & Italy & 2.160 .805 & 2,55 & 75.282 & 4,12 \\
\hline $\mathbf{9}$ & Spain & 1.994 .012 & 2,35 & 53.965 & 2,96 \\
\hline $\mathbf{1 0}$ & Germany & 1.775 .538 & 2,09 & 34.315 & 1,88 \\
\hline $\mathbf{1 1}$ & Colombia & 1.663 .134 & 1,96 & 43.640 & 2,39 \\
\hline $\mathbf{1 2}$ & Argentina & 1.639 .932 & 1,93 & 43.452 & 2,38 \\
\hline $\mathbf{1 3}$ & Mexico & 1.442 .107 & 1,70 & 127.074 & 6,96 \\
\hline $\mathbf{1 4}$ & Poland & 1.335 .535 & 1,57 & 29.167 & 1,60 \\
\hline $\mathbf{1 5}$ & Iran & 1.246 .225 & 1,47 & 55.527 & 3,04 \\
\hline & TOTAL LiST & $\mathbf{6 2 . 2 1 9 . 3 0 2}$ & $\mathbf{7 3 , 3 7}$ & $\mathbf{1 . 3 7 6 . 6 5 4}$ & $\mathbf{7 5 , 4 2}$ \\
\hline & GLOBAL & $\mathbf{8 4 . 8 0 2 . 8 0 3}$ & $\mathbf{1 0 0 , 0 0}$ & $\mathbf{1 . 8 2 5 . 2 1 8}$ & $\mathbf{1 0 0 , 0 0}$ \\
\hline & & & &
\end{tabular}

Considering the data obtained in the first 12 weeks of 2021, the number of cases occurring in the cumulative total of cases seen in January increased more in February and decreased again in March, compared to February, among the countries of the USA, France, Spain, Argentina, and Mexico. It is shown in Graphic-1. When (Figure 1) is examined in detail, cases have gradually increased in Brazil, Russia, Poland and Iran in February and March since January. The percentage of the total number of cases fell in January, February, and March, also in the emerging countries of India, Italy, and Turkey. As a result of the measures taken in England, Germany and Colombia, the cases have decreased continuously in February and March since January. Considering the cumulative total number of cases and total deaths in January, February, and March, case rates and death rates varied at the same rate (Figure 2), (URL 4). When these facts are examined, it is possible to compare the countries that manage the successful process with the countries that manage the successful process and the countries that manage the unsuccessful processes in the first 12 weeks of 2021 with numerical values. 
30.

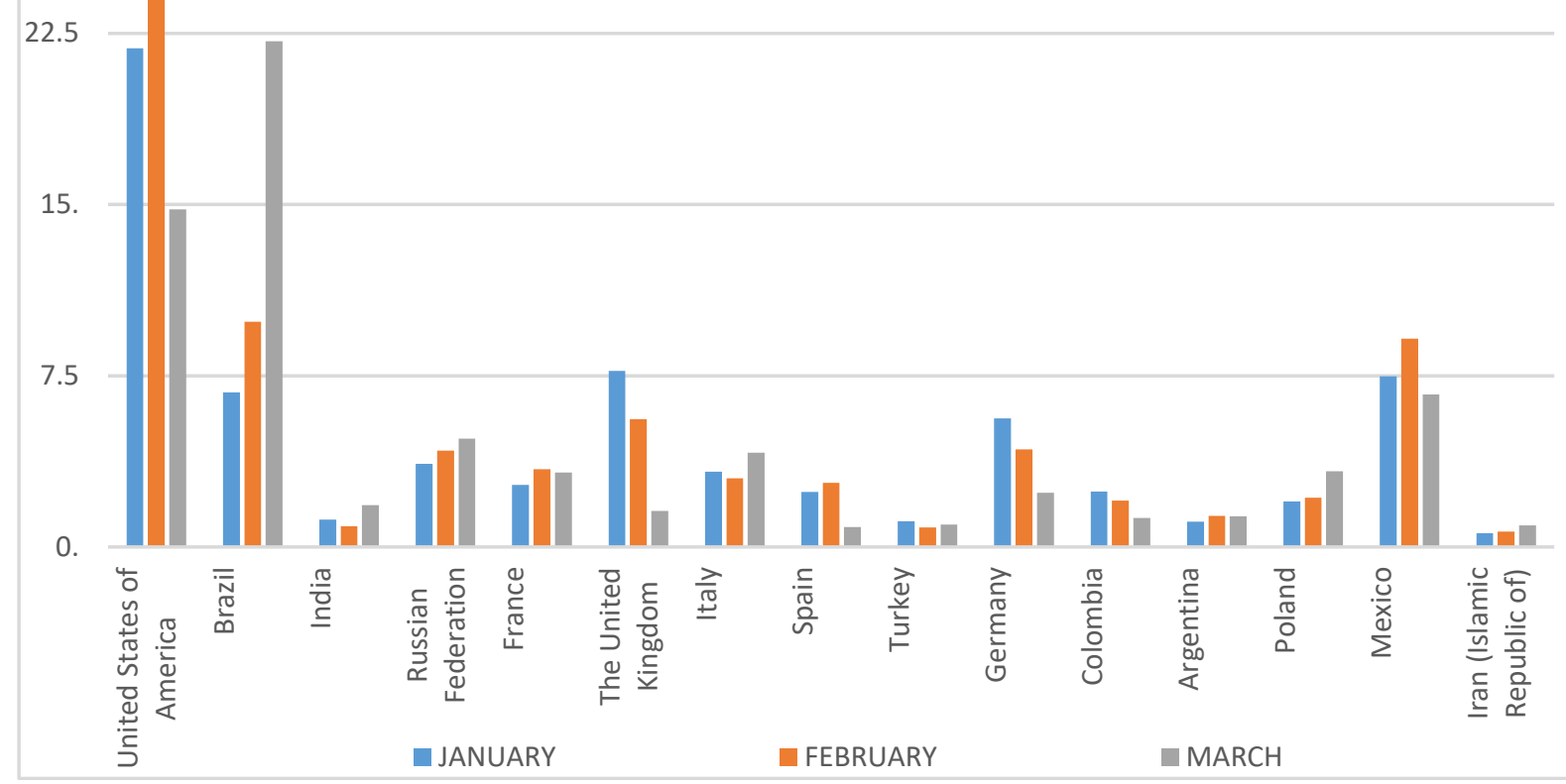

Figure 1. 2021 First 3 Months Confirmed Cases (\%)

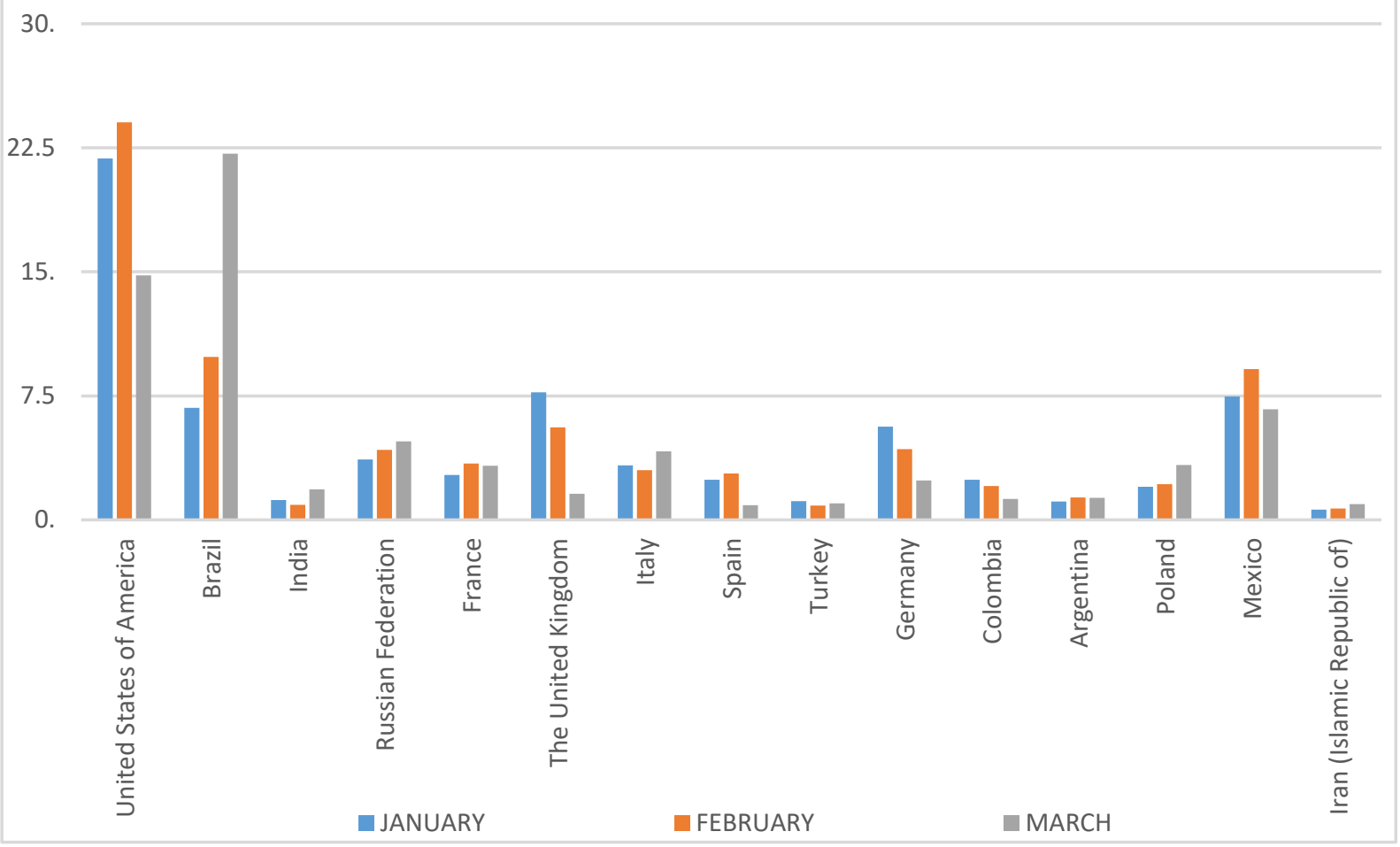

Figure 2. 2021 First 3 Months Deaths (\%) 


\section{CONCLUSION AND RECOMMENDATIONS}

Natural, biological, and man-made disasters quickly overwhelm local governments' ability to function. Nowadays, SARS-CoV-2 has been caused by pandemic episodes that affect a large region, continent, or even worldwide. Controlling the epidemic by getting people sick is not a humane method. It also puts the epidemic into a stagnant period of only short-term prevention. Because although mutations are seen as a method to get rid of the disease, variants of the virus may encounter a stronger version. Vaccination technology is the true process management of epidemiology. Since infectious diseases can turn into different variants in a very short time, community immunity is gained by continuously improving vaccination technology and introducing antibodies to the body at certain time intervals. Therefore, the free spread of the disease and herd immunity typing is more open to discussion than a correct approach. When the vaccination capacity of the countries reaches high levels and vaccine supply is not a problem, those who have the disease will be encouraged to be vaccinated after a certain period time. Since the antibodies caused by the disease reduce the effect of the vaccine, the immunity typing of those who have the disease after 6 months should continue with the memory vaccine strategy. Immune gains by passing the disease are short-term protective methods. Vaccine technology has many scientific folds and some groups in the world that are against vaccination need to be informed separately. Because social immunity, leaving it to the preference of individuals, requires an academic knowledge level of epidemiology, vaccination technology, epidemic management, molecular biology and biochemical. The negative approach of countries, groups or individuals to vaccine immunity that does not have sufficient academic equipment at this level of knowledge spreads the formation of social immunity to a late time. The most effective way to get rid of the pandemic is to vaccinate at least $60-75 \%$ of the total population in a short time. Currently, there is no Covid vaccine application for children worldwide. This situation means that when we remove the children within $60-75 \%$ of society, all individuals above the age of 20 are fully vaccinated. We will not see the effect of vaccination when it is below $60 \%$ of the population in real terms. A certain section of society has been vaccinated, and social immunization approaches as much as the vaccinated section are not accurate risk management. Even if the protection rates as a result of vaccination technology are not $100 \%$, there is a lot of evidence that it prevents severe cases. When vaccination technology advances at this pace, we unfortunately think that we will see the effects of COVID all over the world by 2025, when developed and well-managed countries slow the vaccination rate, case rate too low, and manage a good shutdown process, pandemic until 202223. If they complete risk management successfully, they may enter into a normalization process faster than undeveloped or less developed countries. Outbreaks are very important biological disasters throughout history. The biggest reason for this is that many parameters of pandemic risk management affect our whole life and habits, establish regular surveillance of hand hygiene habits and provide opportunities for vaccination by learning from the SARS experience.

Countries have established many risk management systems against SARS-CoV-2 with the experience they have gained. But the COVID-19 pandemic is changing the whole world order. We have not yet fully seen the effects of COVID-19. The real effects of COVID-19 will appear close to the end of the pandemic or after the pandemic is over. In other words, it will emerge after social immunity is achieved. These effects appear as physiological, psychological, sociological and habits used in daily life. Considering the physiological effects, individuals who have had the disease use a number of antiviral drugs such as Hydroxychloroquine, Chloroquine, Heparin, Azithromycin, Meropenem or Levofloxacin (Mitjà \& Clotet, 2020)(Feng et al., 2020). Based on the Chinese researchers, herbal drugs, Glycyrrhizae Radix et Rhizoma (Gancao), Astragali Radix (Huanggi), Saposhnikoviae Radix (Fangfeng), Lonicerae Japonicae Flos, Macrocephalae Rhizoma (Baizhu), Fructus forsythia (Lianqiao), Armeniacae Semen Amarum, Gypsum Fibrosum, and Ephedra Herba have been frequently used for the symptomatic and antiviral treatments and can be tested for 
COVID-19. However, extensive clinical trials are required to establish the efficacy and safety of these traditional Chinese medicines on humans (Cunningham et al., 2020). When these drugs are considered in the long term, they will take their place as agents that trigger side effects and other diseases in the society. For example; cute generalized exanthematous pustulosis, urticaria, pruritus, dry skin, rashes, flares of psoriasis andexfoliating lesions, Steven s-Johnson-like syndrome, mucocutaneous dyspigmentation, alopecia, and bleaching of hair for Hydroxychloroquine and Chloroquine drugs. On the other hand, cutaneous severe skin reaction associated fever, angioedema, burning in eyes, skin pain, generalized red orpurple skin rashes, blistering, skin peeling, toxic pustuloderma, anaphylaxis, DRESS syndrome, cutaneousleukocytoclastic vasculitis, and fixed drug eruptions for Azithromycin (Türsen et al., 2020).

When looking at other physiological factors, mask use can be another example. Unconscious use of masks may occur. They need plenty of oxygen when doing sports or doing a cardiovascular movement. People may encounter some physiological disorders as a result of insufficient oxygen in such long-term use of wrong masks(Tirupathi et al., 2020). Considering the psychological effects, which are another factor, the fear of going out in old people, the phobia of dying when children are sick, or psychological problems may occur in people (Akgül et al., 2021). In terms of socio-cultural aspects or as a result of changes in our daily lives and habits, adaptation processes will lead to social changes in terms of countries. There will be a transition to the new world order in cinema, theatre, sports competitions, cultural events and events with collective participation. One of the biggest effects of this epidemic in the digital world will be on the economy. The place and size of digital money, bitcoins, contactless spending and online shopping will increase. When all these parameters are evaluated at the same time, it will be difficult for all countries - developed, underdeveloped or underdeveloped - to adapt to the new world order and there will be some problems in the application of the gained experience of the countries. From a risk management perspective, workplaces, schools, concert and entertainment venues, stadiums, or events and activities open to public use that require social distance will be restructured and the experience of countries against COVID-19 will be put into practice. For this reason, we will still feel the effects of COVID-19 close to the end of the pandemic. In this study, in the first quarter of 2021, COVID-19 is viewed as an exemplary assessment of the processes of biological disasters that have existed for many years, have taken shape in a different form today, and will continue in the future. As a result, although there are many prevention strategies such as physical distancing and wearing masks in the current pandemic process, these strategies will paradoxically cause a lack of people's immune response to SARS-CoV-2. According to the R0 value (2.5-3.5) of SARS-CoV-2, which is the causative agent of COVID-19 disease, $60-72 \%$ of the population should be immune to prevent the spread of the virus. Thus, it is thought that the world will not return to a normal state until we successfully implement a global vaccination program (WHO, 2020).

\section{REFERENCES}

Achaiah, N. C., Subbarajasetty, S. B., \& Shetty, R. M. (2020). R0 and Re of COVID-19: Can We Predict When the Pandemic Outbreak will be Contained? Indian Journal of Critical Care Medicine: Peer-Reviewed, Official Publication of Indian Society of Critical Care Medicine, 24(11), 1125. https://doi.org/10.5005/jp-journals10071-23649

Agrawal, A. S., Tao, X., Algaissi, A., Garron, T., Narayanan, K., Peng, B.-H., Couch, R. B., \& Tseng, C.-T. K. (2016). Immunization with inactivated Middle East Respiratory Syndrome coronavirus vaccine leads to lung immunopathology on challenge with live virus. Human Vaccines \& Immunotherapeutics, 12(9), 2351-2356. https://doi.org/https://doi.org/10.1080/21645515.2016.1177688

Ai, T., Yang, Z., Hou, H., Zhan, C., Chen, C., Lv, W., Tao, Q., Sun, Z., \& Xia, L. (2020). Correlation of Chest CT and RT-PCR Testing for Coronavirus Disease 2019 (COVID-19) in China: A Report of 1014 Cases. Radiology. https://doi.org/10.1148/radiol.2020200642 
Akgül, M. Ş., Ozcan, N., Uzun, M. E., Gurses, V. V, \& Baydil, B. (2021). Physiological impact of wearing a surgical face mask during walking in the COVID-19 pandemic. Pedagogy of Physical Culture and Sports, 25(4), 202207. https://doi.org/10.15561/26649837.2021.0401

Alauddin, M., Khan, F., Imtiaz, S., Ahmed, S., \& Amyotte, P. (2021). Pandemic risk management using engineering safety principles. Process Safety and Environmental Protection, 150, 416-432. https://doi.org/10.1016/j.psep.2021.04.014

Ansart, S., Pelat, C., Boelle, P. Y., Carrat, F., Flahault, A., \& Valleron, A. J. (2009). Mortality burden of the 19181919 influenza pandemic in Europe. Influenza and Other Respiratory Viruses, 3(3), 99-106. https://doi.org/10.1111/j.1750-2659.2009.00080.x

Bauch, C. T. (2021). Estimating the COVID-19 R number: a bargain with the devil? In The Lancet Infectious Diseases (Vol. 21, Issue 2, pp. 151-153). Elsevier. https://doi.org/10.1016/S1473-3099(20)30840-9

Blanco-Melo, D., Nilsson-Payant, B. E., Liu, W.-C., Uhl, S., Hoagland, D., Møller, R., Jordan, T. X., Oishi, K., Panis, M., \& Sachs, D. (2020). Imbalanced host response to SARS-CoV-2 drives development of COVID-19. Cell, 181(5), 1036-1045. https://doi.org/https://doi.org/10.1016/j.cell.2020.04.026

Bland, S. A. (2014). Chemical, Biological, Radiological and Nuclear (CBRN) Casualty Management Principles. In Conflict and Catastrophe Medicine (pp. 747-770). Springer. https://doi.org/Doi 10.1007/978-1-44712927-1_46

Cunningham, A. C., Goh, H. P., \& Koh, D. (2020). Treatment of COVID-19: old tricks for new challenges. Springer. https://doi.org/10.1186/s13054-020-2818-6

Daniloski, Z., Jordan, T. X., Wessels, H. H., Hoagland, D. A., Kasela, S., Legut, M., Maniatis, S., Mimitou, E. P., Lu, L., Geller, E., Danziger, O., Rosenberg, B. R., Phatnani, H., Smibert, P., Lappalainen, T., TenOever, B. R., \& Sanjana, N. E. (2021). Identification of Required Host Factors for SARS-CoV-2 Infection in Human Cells. Cell, 184(1), 92-105.e16. https://doi.org/10.1016/j.cell.2020.10.030

Di Mascio, D., Khalil, A., Saccone, G., Rizzo, G., Buca, D., Liberati, M., Vecchiet, J., Nappi, L., Scambia, G., Berghella, V., \& D'Antonio, F. (2020). Outcome of coronavirus spectrum infections (SARS, MERS, COVID-19) during pregnancy: a systematic review and meta-analysis. American Journal of Obstetrics \& Gynecology MFM, 2(2), 100107. https://doi.org/10.1016/j.ajogmf.2020.100107

Dong, E., Du, H., \& Gardner, L. (2020). An interactive web-based dashboard to track COVID-19 in real time. The Lancet Infectious Diseases, 20, doi.org/10.1016/S1473-3099(20)3012. https://doi.org/doi.org/10.1016/S1473-3099(20)30120-1

Feng, G., Zheng, K. I., Yan, Q.-Q., Rios, R. S., Targher, G., Byrne, C. D., Van Poucke, S., Liu, W.-Y., \& Zheng, M.-H. (2020). COVID-19 and liver dysfunction: current insights and emergent therapeutic strategies. Journal of Clinical and Translational Hepatology, 8(1), 18. https://doi.org/10.14218/JCTH.2020.00018

Guo, L., Ren, L., Yang, S., Xiao, M., Chang, D., Yang, F., Dela Cruz, C. S., Wang, Y., Wu, C., Xiao, Y., Zhang, L., Han, L., Dang, S., Xu, Y., Yang, Q. W., Xu, S. Y., Zhu, H. D., Xu, Y. C., Jin, Q., ... Wang, J. (2020). Profiling early humoral response to diagnose novel coronavirus disease (COVID-19). Clinical Infectious Diseases. https://doi.org/10.1093/cid/ciaa310

Hashem, A. M., Algaissi, A., Agrawal, A. S., Al-Amri, S. S., Alhabbab, R. Y., Sohrab, S. S., S. Almasoud, A., Alharbi, N. K., Peng, B.-H., \& Russell, M. (2019). A highly immunogenic, protective, and safe adenovirus-based vaccine expressing Middle East respiratory syndrome coronavirus S1-CD40L fusion protein in a transgenic human dipeptidyl peptidase 4 mouse model. The Journal of Infectious Diseases, 220(10), 1558-1567. https://doi.org/https://doi.org/10.1093/infdis/jiz137

Hsieh, K. Y., Kao, W. T., Li, D. J., Lu, W. C., Tsai, K. Y., Chen, W. J., Chou, L. S., Huang, J. J., Hsu, S. T., \& Chou, F. H. C. (2021). Mental health in biological disasters: From SARS to COVID-19. In International Journal of Social Psychiatry (Vol. 67, Issue 5, pp. 576-586). SAGE Publications Sage UK: London, England. 
Hu, B., Guo, H., Zhou, P., \& Shi, Z.-L. (2021). Characteristics of SARS-CoV-2 and COVID-19. Nature Reviews Microbiology, 19(3), 141-154. https://doi.org/https://doi.org/10.1038/ s41579-020-00459-7

Jasper J. et al. (2017). GISAID Global Initiative on Sharing All Influenza Data. Phylogeny of SARS-like betacoronaviruses including novel coronavirus (nCoV) - BOOK. In Oxford (Vol. 34, Issue 8). https://www.researchgate.net/publication/321428915_SAPP_functional_genome_annotation_and_analys is_through_a_semantic_framework_using_FAIR_principles

Johnson, N. P. A. S., \& Mueller, J. (2002). Updating the accounts: global mortality of the 1918-1920 "Spanish" influenza pandemic. Bulletin of the History of Medicine, 76(1), 105-115. https://doi.org/10.1353/bhm.2002.0022

Khabbaz, R., Bell, B. P., Schuchat, A., Ostroff, S. M., Moseley, R., Levitt, A., \& Hughes, J. M. (2014). Emerging and Reemerging Infectious Disease Threats. In Mandell, Douglas, and Bennett's Principles and Practice of Infectious Diseases (Vol. 1, pp. 158-177). Elsevier. https://doi.org/10.1016/B978-1-4557-4801-3.00014-X

Komurcu, S. Z. M., Artik, Y., Cesur, N. P., Tanriverdi, A., Erdogan, D. C., Celik, S., \& Gulec, E. Y. (2021). The Evaluation Potential Global Impact Of The N501Y Mutation In Sars-Cov-2 Positive Patients. Journal of Medical Virology. https://doi.org/10.1002/JMV.27413

Kwok, K. O., Lai, F., Wei, W. I., Wong, S. Y. S., \& Tang, J. W. T. (2020). Herd immunity - estimating the level required to halt the COVID-19 epidemics in affected countries. In Journal of Infection (Vol. 80, Issue 6, pp. e32-e33). https://doi.org/10.1016/j.jinf.2020.03.027

Kwon, E. H., Reisler, R. B., Cardile, A. P., Cieslak, T. J., D’Onofrio, M. J., Hewlett, A. L., Martins, K. A., Ritchie, C., \& Kortepeter, M. G. (2018). Distinguishing Respiratory Features of Category A/B Potential Bioterrorism Agents from Community-Acquired Pneumonia. In Health Security (Vol. 16, Issue 4, pp. 224-238). Mary Ann Liebert, Inc. 140 Huguenot Street, 3rd Floor New Rochelle, NY 10801 USA. https://doi.org/10.1089/hs.2018.0017

Lam, W. K., Zhong, N. S., \& Tan, W. C. (2003). Overview on SARS in Asia and the World. In Respirology (Vol. 8). https://doi.org/10.1046/j.1440-1843.2003.00516.x

Liao, M., Liu, Y., Yuan, J., Wen, Y., Xu, G., Zhao, J., Cheng, L., Li, J., Wang, X., \& Wang, F. (2020). Single-cell landscape of bronchoalveolar immune cells in patients with COVID-19. Nature Medicine, 26(6), 842-844. https://doi.org/https://doi.org/10.1038/s41591-020-0901-9

Liu, L., Wei, Q., Lin, Q., Fang, J., Wang, H., Kwok, H., Tang, H., Nishiura, K., Peng, J., \& Tan, Z. (2019). Anti-spike IgG causes severe acute lung injury by skewing macrophage responses during acute SARS-CoV infection. JCI Insight, 4(4). https://doi.org/https://doi.org/10.1172/jci.insight.123158

Macnaughton, M. R., \& Davies, H. A. (1987). Coronaviridae. Perspectives in Medical Virology. https://doi.org/10.1016/S0168-7069(08)70094-6

Manning, F. J., \& Goldfrank, L. (2002). Preparing for terrorism: tools for evaluating the metropolitan medical response system program. National Academies Press (US). https://doi.org/https://doi.org/10.17226/10412

Mitjà, O., \& Clotet, B. (2020). Use of antiviral drugs to reduce COVID-19 transmission. The Lancet Global Health, 8(5), e639-e640. https://doi.org/10.1016/S2214-109X(20)30114-5

Morens, D. M., Folkers, G. K., \& Fauci, A. S. (2008). Emerging infections: a perpetual challenge. The Lancet Infectious Diseases, 8(11), 710-719. https://doi.org/10.1016/S1473-3099(08)70256-1

Niska, R. W., \& Burt, C. W. (2005). Bioterrorism and Mass Casualty Preparedness in Hospitals, United States, 2003, BOOK. (Issue 364). US Department of Health and Human Services, Centers for Disease Control. 
Omer, S. B., Yildirim, I., \& Forman, H. P. (2020). Herd Immunity and Implications for SARS-CoV-2 Control. JAMA, 324(20), 2095-2096. https://doi.org/10.1001/jama.2020.20892

Özceylan Aubrecht, D., \& Coşkun, E. (2014). Kimyasal, biyolojik, radyolojik, nükleer (KBRN) Afetlere gerçek zamanlı yanıt sağlayacak bir karar destek sistemi modeli. Yönetim Bilişim Sistemleri Kongresi, 49.

Pehlivan, D., Bayram, Y., Gunes, N., Coban Akdemir, Z., Shukla, A., Bierhals, T., Tabakci, B., Sahin, Y., Gezdirici, A., Fatih, J. M., Gulec, E. Y., Yesil, G., Punetha, J., Ocak, Z., Grochowski, C. M., Karaca, E., Albayrak, H. M., Radhakrishnan, P., Erdem, H. B., ... Lupski, J. R. (2019). The Genomics of Arthrogryposis, a Complex Trait: Candidate Genes and Further Evidence for Oligogenic Inheritance. American Journal of Human Genetics, 105(1), 132-150. https://doi.org/10.1016/j.ajhg.2019.05.015

Public Health England. (2020). Investigation of novel SARS-COV-2 variant: Variant of Concern 202012/01 Technical Briefing $3 . \quad$ In Gov.Uk, BOOK (Issue December). https://www.gov.uk/government/publications/investigation-of-novel-sars-cov-2-variant-variant-ofconcern-20201201

Remy, K. E., Mazer, M., Striker, D. A., Ellebedy, A. H., Walton, A. H., Unsinger, J., Blood, T. M., Mudd, P. A., Yi, D. J., \& Mannion, D. A. (2020). Severe immunosuppression and not a cytokine storm characterizes COVID-19 infections. JCI Insight, 5(17). https://doi.org/https://doi.org/10.1172/jci.insight.140329

Schirmbeck, R., Böhm, W., \& Reimann, J. (1996). Virus-like particles induce MHC class I-restricted T-cell responses. Intervirology, 39(1-2), 111-119. https://doi.org/https://doi.org/10.1159/000150482

Sezen, F. (2009). Influenza pandemics. Türk Hijyen ve Deneysel Biyoloji Dergisi, 66(2, Supplement), 21-24.

Shang, J., Wan, Y., Luo, C., Ye, G., Geng, Q., Auerbach, A., \& Li, F. (2020). Cell entry mechanisms of SARS-CoV2. Proceedings of the National Academy of Sciences of the United States of America, 117(21). https://doi.org/10.1073/pnas.2003138117

Shereen, M. A., Khan, S., Kazmi, A., Bashir, N., \& Siddique, R. (2020). COVID-19 infection: Origin, transmission, and characteristics of human coronaviruses. In Journal of Advanced Research (Vol. 24, pp. 91-98). Cairo University. https://doi.org/10.1016/j.jare.2020.03.005

Shu, Y., \& McCauley, J. (2017). GISAID: Global initiative on sharing all influenza data-from vision to reality. Eurosurveillance, 22(13), 30494. https://doi.org/10.2807/1560-7917.ES.2017.22.13.30494

Simonsen, L., Clarke, M. J., Schonberger, L. B., Arden, N. H., Cox, N. J., \& Fukuda, K. (1998). Pandemic versus epidemic influenza mortality: A pattern of changing age distribution. Journal of Infectious Diseases, 178(1), 53-60. https://doi.org/10.1086/515616

Spengler, J. R., Ervin, E. D., Towner, J. S., Rollin, P. E., \& Nichol, S. T. (2016). Perspectives on West Africa Ebola virus disease outbreak, 2013-2016. Emerging Infectious Diseases, 22(6), 956-963. https://doi.org/10.32032/eid2206.160021

Tirupathi, R., Bharathidasan, K., Palabindala, V., Salim, S. A., \& Al-Tawfiq, J. A. (2020). Comprehensive review of mask utility and challenges during the COVID-19 pandemic. Infez Med, 28(suppl 1), 57-63. https://doi.org/Apsent

Turan, C., \& Hacımustafaoğlu, M. (2020). What is the R0 number and clinical significance in infectious diseases? In Cocuk Enfeksiyon Dergisi (Vol. 14, Issue 1, pp. e47-e48). https://doi.org/10.5578/ced.202008

Türsen, Ü., Türsen, B., \& Lotti, T. (2020). Cutaneous side-effects of the potential COVID-19 drugs. Dermatologic Therapy, 33(4), e13476. https://doi.org/10.1111/dth.13476

URL 1, https://www.cdc.gov/anthrax/bioterrorism/index.htm (Last acceded: 11.09.2021). (n.d.). https://www.cdc.gov/anthrax/bioterrorism/index.htm (Last acceded: 11.09.2021) 
URL 2, https://emergency.cdc.gov/agent (Last Acceded: 11.09.2021). (n.d.).

URL 3, https://apnews.com/article/united-nations-coronavirus-pandemic-china-only-on-ap-bats24fbadc58cee3a40bca2ddf7a14d2955 (Last Acceded: 11.09.2021). (n.d.).

URL 4, https://covid19.who.intv (Last Acceded: 11.09.2021), H. who. int., Https://covid19.who.int/region/amro/country/... (n.d.).

Varol, N., \& Buluş Kırıkkaya, E. (2017). Afetler Karşısında Toplum Dirençliliği. Resilience. https://doi.org/10.32569/resilience.344784

Vellingiri, B., Jayaramayya, K., Iyer, M., Narayanasamy, A., Govindasamy, V., Giridharan, B., Ganesan, S., Venugopal, A., Venkatesan, D., Ganesan, H., Rajagopalan, K., Rahman, P. K. S. M., Cho, S. G., Kumar, N. S., \& Subramaniam, M. D. (2020). COVID-19: A promising cure for the global panic. In Science of the Total Environment. https://doi.org/10.1016/j.scitotenv.2020.138277

Volz, E., Hill, V., McCrone, J. T., Price, A., Jorgensen, D., O’Toole, Á., Southgate, J., Johnson, R., Jackson, B., Nascimento, F. F., Rey, S. M., Nicholls, S. M., Colquhoun, R. M., da Silva Filipe, A., Shepherd, J., Pascall, D. J., Shah, R., Jesudason, N., Li, K., ... Connor, T. R. (2020). Evaluating the effects of SARS-CoV-2 Spike mutation D614G on transmissibility and pathogenicity. MedRxiv, 184(1), 64-75. https://doi.org/10.1016/j.ygeno.2020.09.028

Wang, R., Hozumi, Y., Yin, C., \& Wei, G. W. (2020). Mutations on COVID-19 diagnostic targets. Genomics, 112(6), 5204-5213. https://doi.org/10.1016/j.ygeno.2020.09.028

WHO. (2020). Draft landscape and tracker of COVID-19 candidate vaccines. In Who (Issue June). https://www.who.int/publications/m/item/draft-landscape-of-covid-19-candidate-

vaccines\%0Ahttps://www.who.int/publications/m/item/draft-landscape-of-covid-19-candidate-

vaccines\%0Ahttps://www.who.int/publications/m/item/draft-landscape-of-covid-19-candidate

Workgroup, C. D. C. S. P. (2000). Biological and chemical terrorism: strategic plan for preparedness and response. Recommendations of the CDC Strategic Planning Workgroup. In MMWR. Recommendations and reports : Morbidity and mortality weekly report. Recommendations and reports / Centers for Disease Control, BOOK (Vol. 49, Issue RR-4).

Wu, Zhiwei, Hu, Y., Xu, M., Chen, Z., Yang, W., Jiang, Z., Li, M., Jin, H., Cui, G., \& Chen, P. (2021). Safety, tolerability, and immunogenicity of an inactivated SARS-CoV-2 vaccine (CoronaVac) in healthy adults aged 60 years and older: a randomised, double-blind, placebo-controlled, phase 1/2 clinical trial. The Lancet Infectious Diseases, 21(6), 803-812. https://doi.org/10.1016/S1473-3099(20)30987-7

Wu, Zunyou, \& McGoogan, J. M. (2020). Characteristics of and important lessons from the coronavirus disease 2019 (COVID-19) outbreak in China: summary of a report of 72314 cases from the Chinese Center for Disease Control and Prevention. Jama, 323(13), 1239-1242. https://doi.org/10.1001/jama.2020.2648

Yilmaz Gulec, E., Cesur, N. P., Yesilyurt Fazlioğlu, G., \& Kazezoğlu, C. (n.d.). Effect of different storage conditions on COVID-19 RT-PCR results. Journal of Medical Virology. https://doi.org/10.1002/jmv.27204

Zhou, P., Yang, X. Lou, Wang, X. G., Hu, B., Zhang, L., Zhang, W., Si, H. R., Zhu, Y., Li, B., Huang, C. L., Chen, H. D., Chen, J., Luo, Y., Guo, H., Jiang, R. Di, Liu, M. Q., Chen, Y., Shen, X. R., Wang, X., ... Shi, Z. L. (2020). A pneumonia outbreak associated with a new coronavirus of probable bat origin. Nature, 579(7798), 270-273. https://doi.org/10.1038/s41586-020-2012-7 